EUROPA REGIONUM TOM XXVIII ROK 2016

DOI: $10.18276 /$ er.2016.28-15

\author{
BEATA Meyer, AleKSANDER PANASIUK \\ Uniwersytet Szczeciński
}

\title{
Finansowanie rozwoju turystyki na obszarach przyrodniczo cennych $w$ regionalnych programach operacyjnych w perspektywach finansowych Unii Europejskiej w latach 2007-2013 i 2014-2020
}

\section{Wprowadzenie}

W Polsce regionalna polityka turystyczna jest w kompetencji samorządu wojewódzkiego, który jest odpowiedzialny za wyznaczanie strategii rozwoju turystyki. Na poziomie lokalnym, zadania w zakresie turystyki realizowane są przez samorząd gminny. Istotnym instrumentem działalności samorządów są fundusze europejskie, które za pośrednictwem Regionalnych Programów Operacyjnych oddziałują na poszczególne dziedziny życia społecznego i gospodarczego w regionie, w tym gospodarkę turystyczną. Szczególnym obszarem związanym z finansowaniem unijnym są kwestie związane z środowiskiem przyrodniczym i jego ochroną. Celem opracowania jest przedstawienie zakresu wsparcia $\mathrm{z}$ funduszy unijnych gospodarki turystycznej w dwóch kolejnych perspektywach finansowania Unii Europejskiej w latach 2007-2013 i 2014-2020. Podstawowym problemem wynikającym $\mathrm{z}$ umiejscowienia gospodarki turystycznej w finansowaniu unj̈nym $\mathrm{w}$ dwóch kolejnych perspektywach finansowych jest brak kontynuacji polityki wsparcia gospodarki turystycznej. W okresie 2007-2013 gospodarka turystyczna uzyskała duże wsparcie finansowe, zwłaszcza w obszarze działań prowadzonych przez jednostki samorządu terytorialnego. W perspektywie 2014-2020 finansowanie działań na cele gospodarki turystycznej jest bardzo ograniczone. Zarówno jednostkom samorządu terytorialnego, jak i przedsiębiorstwom i organizacjom turystycznym pozostaje możliwość ubiegania się o wsparcie finansowe na zasadach ogólnodostępnych, niededykowanych bezpośrednio gospodarce turystycznej. Istotnym obszarem wsparcia są $\mathrm{w}$ tym 
przypadku środki związane $\mathrm{z}$ obszarami przyrodniczo cennymi. Cele z zakresu rozwoju gospodarki turystycznej mogą być realizowane przy wykorzystaniu środków finansowych zaplanowanych dla działań związanych z ochroną środowiska przyrodniczego oraz efektywną eksploatacją jego zasobów. $Z$ treści opracowania wynika zatem istotna zmiana w polityce wsparcia rozwoju gospodarki turystycznej, z finansowania bezpośrednio dedykowanego (2007-2013) na rzecz działań finansowanych pośrednio, w tym przy użyciu środków na środowisko przyrodnicze. W tej sytuacji w perspektywie finansowania UE na lata 20142020 szczególnego znaczenia nabiera możliwość rozwoju turystyki na obszarach przyrodniczo cennych. Dzięki środkom UE będących w dyspozycji RPO istnieje możliwość łączenia celów z zakresu środowiska przyrodniczego i turystyki.

\section{Regionalne Programy Operacyjne w finansowaniu rozwoju gospo- darki turystycznej}

Gospodarka turystyczna to system współzależności rynkowych powstających podczas procesu zaspokajania potrzeb zgłaszanych przez turystów pomiędzy realizującymi go przedsiębiorcami $\mathrm{i}$ instytucjami ${ }^{1}$. Tak rozumiany system obejmuje całość działań podmiotów tej gospodarki, które podejmowane są w procesie obsługi ruchu turystycznego ${ }^{2}$. W skład gospodarki turystycznej wchodzą wszystkie podmioty, które kierują swoją działalność na potrzeby turystów i nie są wyłącznie nastawione na obsługę ruchu turystycznego ${ }^{3}$. Warunkiem skutecznego funkcjonowania podmiotów regionalnej i lokalnej gospodarki turystycznej na poziomie regionalnym jest ukształtowanie sytemu współpracy pomiędzy: jednostkami prowadzącymi działalność gospodarczą (przedsiębiorstwami turystycznymi), samorządem wojewódzkim i gminnym, organizacjami i stowarzyszeniami branży turystycznej, w tym samorządu gospodarczego oraz regionalną organizacją turystyczną ${ }^{4}$. Podstawą rolę w kształtowaniu efektów społecznych i ekonomicznych wynikających z funkcjonowania gospodarki turystycznej na poziomie regionalnym posiada samorząd wojewódzki, będący pod-

1 A. Nowakowska, Gospodarka turystyczna w ujęciu systemowym, Folia Eeconomica Cracoviensia, 1988, vol. XXI, s.169-171, A.S. Kornak, A. Rapacz, Zarzadzanie turystyka i jej podmiotami w miejscowości i regionie, Wrocław 2001, s.11, W.W. Gaworecki, Turystyka, Warszawa 2003, s. 161.

${ }^{2}$ B. Meyer (red.), Obstuga ruchu turystycznego, Warszawa 2006, s. 39-40.

${ }^{3}$ S.J. Page, J. Connell, Tourism a modern synthesis, London 2006, s. 16-17.

${ }^{4}$ A. Panasiuk (red), Gospodarka turystyczna, Warszawa 2008, s. 25. 
miotem polityki turystycznej. Do podstawowych celów regionalnej polityki turystycznej, zaliczyć należy: zaspokojenie potrzeb turystycznych społeczeństwa, racjonalne wykorzystanie walorów turystycznych, zasobów pracy i kapitału w sferze gospodarki turystycznej, ksztaltowanie optymalnych rozmiarów i struktury ruchu turystycznego, koordynowanie rozwoju turystyki, z uwzględnieniem jej różnych funkcji oraz związków z innymi sferami życia gospodarcze$\mathrm{go}^{5}$.

Kompetencje samorządu regionalnego kierują się przede wszystkim na funkcjonowanie tzw. bezpośredniej gospodarki turystycznej, obejmującej oddziaływanie na podmioty rynku turystycznego, których funkcjonowanie wynika z realizacji zapotrzebowania zgłaszanego bezpośrednio przez turystów, tj. hotelarstwo, gastronomię, turystyczny transport pasażerski, biura podróży, podmioty udostępniające atrakcje turystyczne, informację turystyczną, działalność organizacji turystycznych, a także jednostki samorządu terytorialnego (głównie gminnego) obszarów atrakcyjnych turystycznie ${ }^{6}$. Potencjalnymi beneficjentami środków unijnych kierowanych do gospodarki turystycznej są podmioty bezpośredniej gospodarki turystycznej oraz jak wynika z praktyki, przede wszystkim jednostki samorządu lokalnego.

Unia Europejska wypracowała procedurę tzw. perspektyw budżetowych, będących formułą planowania i finansowania zadań w okresach siedmioletnich. Od 2004 r. Polska jako członek UE korzystała bezpośrednio ze środków, które były określone kolejnymi perspektywami finansowymi na lata 2000-2006, 2007-2013 oraz korzysta w bieżącym okresie na lata 2014-2020.

Największym źródłem finansowania inicjatyw turystycznych z funduszy Unii Europejskiej jest Europejski Fundusz Rozwoju Regionalnego (EFRR), a w jego ramach 16 Regionalnych Programów Operacyjnych (RPO) na poziomie poszczególnych województw Polski. Głównym zadaniem EFRR jest finansowanie programów unijnych, które mają na celu pomoc najsłabiej rozwiniętym regionom UE. W perspektywie 2007-2013 jednym z celów strategic znych wsparcia $\mathrm{w}$ ramach EFRR był między innymi rozwój turystyki oraz inwestycji w dziedzinie kultury. Wskazany cel stanowił podstawową oś finansowania działań, będąc podstawą dla rozwoju turystyki w obszarach objętych wsparciem. W per-

\footnotetext{
${ }^{5}$ W. Kurek (red.), Turystyka, Warszawa 2007, s. 388.

${ }^{6}$ A. Panasiuk, Rynek turystyczny. Studium strukturalne, Warszawa 2014, s. 27-33.
} 
spektywie 2014-2020 istotnym obszarem wsparcia jest ochrona dziedzictwa środowiska przyrodniczego.

Główne cele rozwojowe określone w ramach EFRR znalazły swoje odzwierciedlenie w każdym z 16 Regionalnych Programów Operacyjnych polskich województw w kolejnych perspektywach finansowych. Podstawę prawną budowy oraz wdrażania RPO w Polsce stanowi Ustawa z 6 grudnia 2006 r. o zasadach prowadzenia polityki rozwoju? ${ }^{7}$ W myśl jej zapisów RPO są dokumentami planistycznymi określającymi obszary i działania, jakie organy samorządu województwa podejmują lub zamierzają podjąć w zakresie wspierania rozwoju regionu. Mają one charakter operacyjny co oznacza, iż zawarte w nich działania stanowią uszczegółowienie i są podrzędne względem założeń regionalnych strategii rozwojowych, jak również regionalnych strategii sektorowych. Jak już zaznaczono zarządzanie (przygotowanie oraz wdrażanie) RPO zostało powierzone zarządom poszczególnych województw, co świadczy o decentralizacji polityki rozwoju w Polsce oraz ma na celu zwiększenie efektywności wykorzystania funduszy w regionach.

Struktura wszystkich 16 Regionalnych Programów Operacyjnych w Polsce składa się z osi priorytetowych, wskazujących na główne obszary wsparcia poszczególnych RPO. W ich ramach wyszczególniono działania i poddziałania określające konkretne grupy przedsięwzięć podlegających finansowaniu w ramach programu.

\section{Turystyka na obszarach przyrodniczo cennych}

Obszary przyrodniczo cenne należy rozumieć, jako obszary o wysokiej różnorodności biologicznej, na których gospodarowanie ich zasobami musi odbywać się w sposób zaplanowany i zrównoważony ${ }^{8}$. Obszary te są ważnym czynnikiem rozwoju wielu form turystyki, w tym m.in.: ekoturystyki, turystyki krajoznawczej, turystyki specjalistycznej, agroturystyki. Dobra turystyczne stają się celem przyjazdów turystów, decydując o sile potencjału turystycznego ${ }^{9}$. Tereny charakteryzujące się korzystnymi dla człowieka czynnikami atmosferycz-

${ }^{7}$ Ustawa 6 grudnia 2006 r. o zasadach prowadzenia polityki rozwoju (t.j.), (DzU 2006, nr 227 poz. 1658).

${ }^{8}$ P. Żegleń, Zarządzanie turystka naobszarach przyrodniczo cennych województwa podkarpackiego, w: M. Jalinik (red.), Turystyka na obszarach przyrodniczo cennych, Biały stok 2010, s. 549-550.

9 A. Panasiuk, Rola informacji turystycznej $w$ ksztaltowaniu potencjatu turystycznego na przykładzie gmin województwa zachodniopomorskiego, „Ekonomiczne Problemy Usług” 2010, nr 53, s. 229-231. 
nymi i biosferycznymi tworzą obszary o walorach przyrodniczo cennych i tym samym są one intensywnie użytkowane przez turystów. Istniejące i potencjalne obszary przyrodniczo cenne powinny nie tylko być powszechnie dostępne wedhug określonych zasad, ale także powinny być objęte określonymi regulacjami prawnymi ograniczającymi nadmierną antropopresję turystyczną. Obecność turystów na obszarach przyrodniczo cennych i ich różne zachowania mogą prowadzić do negatywnych skutków ${ }^{10}$. Dlatego też, stosowana regulacja powinna wpływać na eliminację konfliktu turysta - przyroda, przy zapewnieniu wspótistnienia przyrody z turystami i turystów z przyrodą ${ }^{11}$.

Obszary przyrodniczo cenne są istotnym czynnikiem rozwoju turystyki. W grupie tej znajdują się obszary chronione, które występują głównie w postaci parków narodowych i krajobrazowych, rezerwatów przyrody, pomników przyrody.

W polskim ustawodawstwie wyodrębniono następujące formy ochrony przyrody:

a) formy ochrony obszarowej (tradycyjne - parki narodowe i rezerwaty przyrody, nowe - parki krajobrazowe i obszary chronionego krajobrazu),

b) formy ochrony obiektowej - pomniki przyrody, stanowiska dokumentacyjne, użytki ekologiczne, zespoły przyrodniczo-krajobrazowe,

c) formy ochrony gatunkowej flory i fauny ${ }^{12}$.

W perspektywie finansowej UE na lata 2007-2013, dzięki rozwojowi turystyki obszary chronione były istotnym elementem rozwoju lokalnego i regionalnego. Obszary przyrodniczo cenne stanowią przedmiot polityki europejskiej i znajdują swoje miejsce w finansowaniu za pośrednictwem RPO w perspektywie 2014-2020. Zadania w tym zakresie mogą być łączone z celami z zakresu funkcjonowania gospodarki turystycznej.

\section{Regionalne Programy Operacyjne jako źródło finansowania rozwoju turystyki w perspektywie finansowej UE na lata 2007-2013}

W perspektywie finansowej na lata 2007-2013 w RPO turystyka wraz z kulturą znalazły się wśród głównych osi priorytetowych aż 14 programów

${ }^{10}$ A. Panasiuk, Struktura oferty turystycznej na obszarach przyrodniczo cennych, „Ekonomia i Środowisko" 2015, nr 3(54), s. 187.

${ }^{11}$ J. Sikora, Możliwości rozwoju turystyki na obszarach przyrodniczo cennych w Wielkopolsce, w: M. Jalinik (red.), Turystyka na obszarach przyrodniczo cennych, Białystok 2010, s. 180-181.

${ }^{12}$ Ustawa z 16 kwietnia 2004 r. o ochronie przyrody, (DzU nr 92, poz. 880, z późn. zm.). 
regionalnych. Tak ważne miejsce turystyki $\mathrm{w}$ analizowanych dokumentach wskazywać może również na wysoką rangę turystyki wśród głównych determinant rozwojowych poszczególnych regionów Polski. Wyjątek w tym zakresie stanowiły Regionalne Programy Operacyjne województw łódzkiego oraz opolskiego gdzie inicjatywy związane $\mathrm{z}$ rozwojem turystyki wyodrębnione zostały dopiero na poziomie działań priorytetowych RPO.

Wśród podstawowych działań zawartych w osiach priorytetowych wiązanych $\mathrm{z}$ rozwojem turystyki $\mathrm{w}$ analizowanych regionach dominowały związane $\mathrm{z}$ :

- budową, rozbudową i modernizacją bazy turystycznej regionów,

- budową, rozbudową i modernizacją publicznej infrastruktury turystycznej i rekreacyjnej,

- tworzeniem regionalnych oraz ponadregionalnych produktów turystycznych,

- tworzeniem regionalnych systemów informacji turystycznej,

- promocją turystyki (w ujęciu krajowym oraz międzynarodowym).

Dodatkowym źródłem finansowania inwestycji turystycznych zapisanym w ramach analizowanych RPO stały się także priorytety związane $\mathrm{z}$ rewitalizacją przestrzeni miejskich i rozwojem obszarów metropolitalnych oraz rozwojem i modernizacją infrastruktury społecznej w tym także kulturowej. W ich ramach wyodrębniono działania obejmujące między innymi:

- rozwój infrastruktury turystycznej na obszarach metropolitalnych oraz tworzenie i promocję lokalnych produktów turystycznych,

- rewitalizację zdegradowanych przestrzeni miejskich oraz dostosowanie ich dla potrzeb turystyki,

- budowę, rozbudowę i modernizację obiektów infrastruktury kulturalnej jako elementów poprawiających atrakcyjność turystyczną obszaru,

- wspieranie ochrony dziedzictwa kulturowego obszarów oraz inwestycje w obiekty kulturowe i historyczne.

Choć głównym celem wskazanych działań, w myśl zapisów poszczególnych RPO, miała być poprawa jakości życia społeczności danego obszaru to jednak w grupach celów szczegółowych większości programów wskazano na istotną rolę tego typu przedsięwzięć w podnoszeniu atrakcyjności turystycznej regionu.

W perspektywie 2007-2013 spośród 16 PRO, tylko w trzech wynikają jednoznaczne powiązania pomiędzy realizacją celów w zakresie turystyki oraz środowiska przyrodniczego. $\mathrm{W}$ jednym przypadku taka relacja dotyczy jednej z osi priorytetowych $\mathrm{w}$ województwie mazowieckim (Wykorzystanie walorów natu- 
ralnych i kulturowych dla rozwoju i turystyki i rekreacji). W dwóch przypadkach dotyczy to poziomu działań. W województwie kujawsko-pomorskim w ramach osi priorytetowej Wsparcie rozwoju turystyki, określono działanie - Rozwój usług turystycznych w oparciu o zasoby turystyczne. W województwie pomorskim w osi priorytetowej Turystyka i dziedzictwo kulturowe, określone zostało działanie - Wspieranie i zachowanie walorów przyrodniczych ${ }^{13}$. W pozostałych regionach finansowanie turystyki na obszarach przyrodniczo cennych mogło się odbywać potencjalnie przez inne działania, ale bez konkretnie wyodrębnionych środków na tego typu cele.

Łączna pula środków alokowanych $\mathrm{w}$ ramach priorytetów związanych bezpośrednio z turystyką wszystkich 16 RPO wynosiła 1,22 mld EUR co stanowi ponad 6\% ogółu środków RPO. Uwzględniając dodatkowo kwoty alokacji z priorytetów pośrednio związanych z rozwojem gospodarki turystycznej w poszczególnych regionach kwota ta wyniosła 2,77 mld EUR i stanowiła 14\% sumy środków RPO.

Z przeprowadzonych wynika, że brak bezpośrednich związków pomiędzy rolą danego regionu w obsłudze ruchu turystycznego, a poziomem zaangażowania środków RPO na działania związane $\mathrm{z}$ rozwojem regionalnej gospodarki turystycznej. Przykładem mogą tu być województwa pomorskie oraz małopolskie, które stanowią jedne $\mathrm{z}$ najpopularniejszych destynacji turystycznych w kraju, a wysokość środków przyporządkowanych na działania proturystyczne w ramach obu programów wyniosły odpowiednio 3,4\% i 6,3\% ogółu środków budżetu RPO. W perspektywie 2007-2013 cele z zakresu turystyki na obszarach przyrodniczo cennych mogły być finansowane ze środków dedykowanych gospodarce turystycznej. W kolejnej perspektywie zakres polityki UE w tym zakresie jest zupetnie odmienny.

\section{Regionalne Programy Operacyjne jako źródła finansowania tury- styki na obszarach przyrodniczo cennych w perspektywie finanso- wej Unii Europejskiej na lata 2014-2020}

W nowej perspektywie finansowej na lata 2014-2020 zagwarantowano ograniczone środki na projekty turystyczne. Jest to istotna zmiana w unijnej polityce,

${ }^{13}$ www.funduszeeuropejskie.gov.p1 (9-11.07.2013), A. Panasiuk (red.), Fundusze Unii Europejskiej w gospodarce turystycznej, Warszawa 2014, s. 118-121. 
która bezpośrednio warunkuje zakres polityki prowadzonej przez poszczególne kraje członkowskie. Część zadań finansowanych w ubiegłej perspektywie może być w pewnym zakresie kontynuowana, ale nie dzięki środkom, które są dedykowane wyłącznie gospodarce turystycznej. Na poziomie regionalnym działania finansowane za pośrednictwem RPO dotyczą głównie:

- rozwoju markowych regionalnych produktów turystycznych,

- promocji turystyki kulturowej i dziedzictwa przemysłowego,

- wspierania rozwoju nowych form turystyki ${ }^{14}$.

Tabela 1 prezentuje miejsce turystyki w RPO poszczególnych polskich województw wraz z zaznaczeniem osi priorytetowych i działań dotyczących finansowania zagadnień z obszaru turystyki na obszarach przyrodniczo cennych.

Generalnie osie priorytetowe oraz szczegółowe działania w RPO w perspektywie 2014-2020 dotyczą tylko pośrednio turystyki. W szczegółowy zakres finansowania zadań w tym okresie turystyka jest wpisana, tylko jako element bardziej obszernej grupy działań. Stąd nie ma możliwości stwierdzenia jakie środki z poszczególnych RPO trafić mogą do gospodarki turystycznej. Podstawowym źródłem finansowania turystyki są działania związane ze środowiskiem przyrodniczym oraz jego zasobami. Łączenie tych zagadnień staje się podstawową przesłanką oddziaływania na regionalny i lokalny rozwój turystyki.

Podmiotom gospodarki turystycznej pozostaje ponadto znalezienie innych możliwości finansowania ze środków RPO, odwołujących się do innych obszarów gospodarki, które pośrednio dotyczyć mogą turystyki ${ }^{15}$. Stąd podmioty gospodarki turystycznej powinny poszukiwać możliwości aplikowania o środki przewidziane np. dla: kultury, sportu i rekreacji, infrastruktury (w tym transportowej), innowacji, przemysłu kreatywnego (sztuka, media i rozrywka, usługi biznesu kreatywnego - architektura, wydawnictwa, reklama), sektora małych i średnich przedsiębiorstw, rozwojów obszarów wiejskich, rynku pracy, wsparcia udzielanego ekonomicznie słabszym grupom społecznym. Zadania te mogą być także łączone z celami na obszarach przyrodniczo cennych.

${ }^{14}$ T. Buczak, Fundusze europejskie w nowej perspektywie finansowej 2014-2020, Warszawa 2014, O. Piekarzewska, Turystyka w nowej perspektywie finansowej Unii Europejskiej, Kraków 2014.

${ }^{15}$ A. Panasiuk (red.), Fundusze..., op. cit., s. 279-293. 
Miejsce turystyki w Regionalnych Programach Operacyjnych w Polsce w latach 2014-2020 ze szczególnym uwzględnieniem zagadnień turystyki na obszarach przyrodniczo cennych

\begin{tabular}{|c|c|c|}
\hline Województwo & Oś priorytetowa & Działanie \\
\hline Dolnośląskie & 4. Środowisko i zasoby & $\begin{array}{l}\text { 4.4. Ochrona i udostępnianie zasobów } \\
\text { przyrodniczych }\end{array}$ \\
\hline $\begin{array}{l}\text { Kujawsko- } \\
\text { pomorskie }\end{array}$ & $\begin{array}{l}\text { 4. Region przyjazny } \\
\text { środowisku }\end{array}$ & $\begin{array}{l}\text { 4.6. Ochrona środowiska naturalnego iż zasobów } \\
\text { kulturowych na obszarze Zintegrowanych } \\
\text { Inwestycji Terytorialnych }\end{array}$ \\
\hline \multirow[b]{3}{*}{ Lubelskie } & \multirow{3}{*}{$\begin{array}{l}\text { 1. Ochrona dziedzictwa } \\
\text { kulturowego i naturalnego }\end{array}$} & 7.2. Ochrona różnorodności przyrodniczej \\
\hline & & 7.3. Turystyka przyrodnicza \\
\hline & & $\begin{array}{l}\text { 7.4. Ochrona bioróżnorodności dla Zintegrowa- } \\
\text { ny ch Inwestycji Terytorialnych Lubelskiego } \\
\text { Obszaru Funkcjonalnego }\end{array}$ \\
\hline \multirow{2}{*}{ Lubuskie } & \multirow{2}{*}{ 4. Środowisko i kultura } & 4.4.Zasoby kulturyidziedzictwakulturowego \\
\hline & & 4.5. Kap itał przyrodniczy regionu \\
\hline \multirow{3}{*}{ Łódzkie } & 5. Ochrona środowiska & 5.4. Ochrona przyrody \\
\hline & \multirow{2}{*}{$\begin{array}{l}\text { 6. Rewitalizacja i potencjał } \\
\text { endogeniczny regionu }\end{array}$} & 6.1. Dziedzictwo kulturowe i infrastruktura kultury \\
\hline & & 6.2. Rozwój gospodarki turystycznej \\
\hline \multirow{3}{*}{ Małopolskie } & \multirow{3}{*}{ 6. Dziedzictwo regionalne } & 6.1. Rozwój dziedzictwa kulturowego i naturalnego \\
\hline & & 6.2. Ochrona różnorodności biologicznej \\
\hline & & 6.3. Rozwój wewnętrznych potencjałów regionów \\
\hline \multirow{2}{*}{ Mazowieckie } & \multirow{2}{*}{$\begin{array}{l}\text { 5. Gospodarka przyjazna } \\
\text { środowisku }\end{array}$} & 5.3. Dziedzictwo kulturowe \\
\hline & & 5.4. Ochrona bioróżnorodności \\
\hline Opolskie & $\begin{array}{l}\text { 5. Ochrona środowiska. Dziedzic- } \\
\text { twa kulturowego i naturalnego } \\
\end{array}$ & $\begin{array}{l}\text { 5.3. Zwiększona dostępność zasobów } \\
\text { kulturowych regionu }\end{array}$ \\
\hline Podkarpackie & $\begin{array}{l}\text { 4. Ochrona środowiska naturalne- } \\
\text { go i dziedzictwa kulturowego }\end{array}$ & 4.4. Kultura \\
\hline Podlaskie & $\begin{array}{l}\text { 6. Ochrona środowiska i racjonal- } \\
\text { ne gospodarowanie jego zasobami }\end{array}$ & $\begin{array}{l}\text { 6.3. Ochrona zasobów bio- i georóżnrodności } \\
\text { oraz krajobrazu }\end{array}$ \\
\hline \multirow{3}{*}{ Pomorskie } & \multirow[b]{2}{*}{ 8. Konwersja } & 8.3. Materialne iniematerialne dziedzictwo kulturowe \\
\hline & & $\begin{array}{l}\text { 8.4. Wsparcie atrakcyjności walorów dziedzictwa } \\
\text { przyrodniczego }\end{array}$ \\
\hline & 11. Srodowisko & 11.4. Ochrona różnorodności biologicznej \\
\hline \multirow{2}{*}{ Śląskie } & \multirow{2}{*}{$\begin{array}{l}\text { 5. Ochrona środowiska i efektywne } \\
\text { wy korzystanie zasobów }\end{array}$} & 5.3. Dziedzictwokulturowe \\
\hline & & 5.4. Ochrona różnorodności biologicznej \\
\hline \multirow[t]{2}{*}{ Świętokrzyskie } & \multirow{2}{*}{$\begin{array}{l}\text { 4. Dziedzictwo naturalne } \\
\text { i kulturowe }\end{array}$} & $\begin{array}{l}\text { 4.4. Zachowanie dziedzictwa kulturowego } \\
\text { i naturalnego }\end{array}$ \\
\hline & & $\begin{array}{l}\text { 4.5. Ochrona i wykorzystanieobszarów cennych } \\
\text { przyrodniczo }\end{array}$ \\
\hline
\end{tabular}




\begin{tabular}{|c|c|c|}
\hline Województwo & Oś priorytetowa & Działanie \\
\hline \multirow{3}{*}{$\begin{array}{l}\text { Warmińsko- } \\
\text {-mazurskie }\end{array}$} & \begin{tabular}{|l|} 
5. Srodowiskoprzyrodnicze \\
i racjonalne wykorzystanie zasobów \\
\end{tabular} & 5.3. Ochrona różnorodności biologicznej \\
\hline & \multirow{2}{*}{ 6. Kultura i dziedzictwo } & 6.1. Infrastruktura kultury \\
\hline & & 6.2. Dziedzictwo naturalne \\
\hline Wielkopolskie & 4. Środowisko & $\begin{array}{l}\text { 4.4. Zachowanie, ochrona, promowanie i rozwój } \\
\text { dziedzictwa naturalnego i kulturalnego } \\
\end{array}$ \\
\hline \multirow[b]{2}{*}{$\begin{array}{l}\text { Zachodnio- } \\
\text {-p omorskie }\end{array}$} & \multirow[b]{2}{*}{$\begin{array}{l}\text { 4. Naturalne otoczenie } \\
\text { człowieka }\end{array}$} & 4.1.Dziedzictwokulturowe \\
\hline & & $\begin{array}{l}\text { 4.2. Wzmocnienie instytucji kultury } \\
\text { 4.5. Wsparcie infrastrukturalnych form ochrony } \\
\text { przyrody i krajobrazu }\end{array}$ \\
\hline
\end{tabular}

Brak wyróżnienia - osie priorytetowe orazdziałania wktórych istnieje zbieżność finansowania zadań z zakresu turystyki i obszarów przyrodniczo cennych.

Źródło: www.funduszeeuropejskie.gov.pl (data dostępu 2-5.07.2016r. ).

\section{Podsumowanie}

Przeprowadzona analiza dostępności środków Unii Europejskiej na rozwój regionalnej gospodarki turystycznej w dwóch kolejnych okresach programowania UE, wskazuje na wiele niejednoznaczności, a przede wszystkim na brak kontynuacji. Znaczący napływ środków UE do gospodarki turystycznej w okresie 20072013, mimo dużego strumienia zasileń, nie był wystarczająco efektywny. Głównym beneficjatem środków na projekty turystyczne były jednostki samorządu lokalnego, a finansowane cele obejmowały często oddziaływanie na rozwój infrastruktury lokalnej (kulturalnej, rekreacyjnej i sportowej), odpowiadając na potrzeby mieszkańców, a nie konieczne bezpośrednio na potrzeby turystów. Zadania z zakresu turystyki i środowiska przyrodniczego posiadły ograniczone możliwości wsparcia. $Z$ zapisów RPO taka możliwość dotyczyła tylko trzech województw.

W perspektywie 2014-2020 gospodarka turystyczna została zepchnięta na margines finansowania unijnego. Najistotniejszy zakres powiązań związanych z dostępem do środków UE na cele turystyczne obejmuje osie priorytetowe i działania w poszczególnych RPO w obszarze zagadnień środowiska przyrodniczego, a głównie ochrony jego dziedzictwa. Wszystkie województwa zadania z zakresu środowiska przyrodniczego wpisały do osi priorytetowych, umiejscawiając w ramach ich działania związane $\mathrm{z}$ turystyką na obszarach przyrodniczo cennych. Do zakończenia perspektywy finansowej UE na lata 2014-2020, tj. do 
2022 roku należy oczekiwać realizacji projektów turystycznych związanych z udostępnianiem obszarów przyrodniczo cennych turystom oraz związanych z tym markowych produktów turystycznych. Działania te będą podobnie jak w minionej perspektywie prowadzone przede wszystkim przez podmioty samorządu terytorialnego.

\section{Bibliografia}

Buczak T., Fundusze europejskie w nowej perspektywie finansowej 2014-2020, Warszawa 2014.

Gaworecki W.W., Turystyka, Warszawa 2003.

Kornak A.S., Rapacz A., Zarządzanie turystyka $i$ jej podmiotami $w$ miejscowości i regionie, Wrocław 2001.

Kurek W. (red.), Turystyka, Warszawa 2007.

Meyer B. (red.), Obstuga ruchu turystycznego, Warszawa 2006.

Nowakowska A., Gospodarka turystyczna w ujęciu systemowym, „Folia Eeconomica Cracoviensia" 1988, vol. XXI.

Page S.J., Connell J., Tourism a modern synthesis, London 2006.

Panasiuk (red.), Fundusze Unii Europejskiej w gospodarce turystycznej, Wars zawa 2014.

Panasiuk A. (red.), Gospodarka turystyczna, Warszawa 2008.

Panasiuk A., Rola informacji turystycznej w kształtowaniu potencjału turystycznego na przykładzie gmin województwa zachodniopomorskiego, Ekonomiczne Problemy Usług, nr 53. 2010.

Panasiuk A., Rynek turystyczny. Studium strukturalne, Warszawa 2014.

Panasiuk A., Struktura oferty turystycznej na obszarach przyrodniczo cennych, Ekonomia i Środowisko, nr 3(54), 2015.

Piekarzewska O., Turystyka $w$ nowej perspektywie finansowej Unii Europejskiej, Kraków 2014.

Sikora J., Możliwości rozwoju turystyki na obszarach przyrodniczo cennych w Wielkopolsce, w: M. Jalinik (red.), Turystyka na obszarach przyrodniczo cennych, Białystok 2010.

Ustawa z dnia 6 grudnia 2006 r. o zasadach prowadzenia polityki rozwoju (t.j.), (DzU 2006, nr 227 poz. 1658).

Ustawa z 16 kwietnia 2004 r. o ochronie przyrody, (DzU nr 92, poz. 880, z późn. zm.)

Żegleń P., Zarzadzanie turystka na obszarach przyrodniczo cennych województwa podkarpackiego, w: M. Jalinik (red.), Turystyka na obszarach przyrodniczo cennych, Białystok 2010.

www.funduszeeuropejskie.gov.pl, A. Panasiuk (red.), Fundusze Unii Europejskiej w gospodarce turystycznej, Warszawa 2014, s. 118-121, (dostęp 9-11.07.2013). 
Financing of tourism development in environmentally valuable areas in the regional operational programs in the European Union's financial perspectives for 2007-2013 and 2014-2020

\begin{abstract}
Summary
An important instrument of local government activities are European funds, which through the Regional Operational Programmes impact on particular areas of social and economic life in the region. Specific areas of support in successive EU financial perspectives are the tourism economy and the natural environment and the protection of its resources. The aim of this paper is to present a range of EU funding tou rism economy in the next two perspectives financing of the European Union in 2007-2013 and 2014 2020. In the period 2007-2013 tourism economy received strong financial support, especially in the area of the activities carried out by local government units. In the 2014 2020 funding activities for the purposes of tourism is heavily restricted. An important area of support in the case of measures related to protected areas (natural and valuable). Objectives for the development of tourism economy can be implemented using the funding planned for the activities related to the protection of the natural environment and the effective exploitation of its resources. The content development is therefore due to a significant change in policy to support the development of tourism, with funding directly dedicated (2007-2013) for the actions financed indirectly, including by means on the natural environment.
\end{abstract}

